\title{
Investigation of Parameters Affecting Gypsum Dewatering Properties in a Wet Flue Gas Desulphurization Pilot Plant
}

\author{
Hansen, Brian Brun; Kiil, Søren
}

Published in:

Industrial \& Engineering Chemistry Research

Link to article, DOI:

$10.1021 / \mathrm{ie} 3005435$

Publication date:

2012

Document Version

Publisher's PDF, also known as Version of record

Link back to DTU Orbit

Citation (APA):

Hansen, B. B., \& Kiil, S. (2012). Investigation of Parameters Affecting Gypsum Dewatering Properties in a Wet Flue Gas Desulphurization Pilot Plant. Industrial \& Engineering Chemistry Research, 51(30), 10100-10107. https://doi.org/10.1021/ie3005435

\section{General rights}

Copyright and moral rights for the publications made accessible in the public portal are retained by the authors and/or other copyright owners and it is a condition of accessing publications that users recognise and abide by the legal requirements associated with these rights.

- Users may download and print one copy of any publication from the public portal for the purpose of private study or research.

- You may not further distribute the material or use it for any profit-making activity or commercial gain

- You may freely distribute the URL identifying the publication in the public portal 


\title{
Investigation of Parameters Affecting Gypsum Dewatering Properties in a Wet Flue Gas Desulphurization Pilot Plant
}

\author{
Brian B. Hansen* and Søren Kiil \\ Department of Chemical and Biochemical Engineering, Technical University of Denmark, DTU, Building 229, DK-2800 Kgs. Lyngby, \\ Denmark
}

\begin{abstract}
Wet flue gas desulphurization (FGD) plants with forced oxidation, installed at coal and oil fired power plants for removal of $\mathrm{SO}_{2}(\mathrm{~g})$, must produce gypsum of high quality. However, quality issues such as an excessive moisture content, due to poor gypsum dewatering properties, may occur from time to time. In this work, the particle size distribution, morphology, and filtration rate of wet FGD gypsum formed in a pilot-scale experimental setup, operated in forced oxidation mode, have been studied. The influence of holding tank residence time $(10-408 \mathrm{~h})$, solids content $(30-169 \mathrm{~g} / \mathrm{L})$, and the presence of impurities $\left(0.002 \mathrm{M} \mathrm{Al}_{2} \mathrm{~F}_{6} ; 50 \mathrm{~g}\right.$ quartz/L; $0.02 \mathrm{M} \mathrm{Al}^{3+}$, and $\left.0.040 \mathrm{M} \mathrm{Mg}^{2+}\right)$ were investigated. In addition, slurry from a full-scale wet FGD plant, experiencing formation of flat shaped crystals and poor gypsum dewatering properties, was transferred to the pilot plant to test if the plant would now start to produce low quality gypsum. The crystals formed in the pilot plant, on the basis of the fullscale slurry did, however, show acceptable filtration rates and crystal morphologies closer to the prismatic crystals from after pilot plant experiments with demineralized water. The gypsum slurry filtration rates were generally high, but a shorter residence time $(10 \mathrm{~h})$ and gypsum crystals experiencing breakage and/or attrition $(408 \mathrm{~h})$ showed slightly lower filtration rates. Both these experiments contained a higher fraction of fines, which may explain the slightly lower filtration rates. Crystals formed at a higher solids concentration and longer residence time $(169 \mathrm{~g} / \mathrm{L}$ and $120 \mathrm{~h})$ showed a higher proportion of flat crystals, and the XRD pattern contained strong peaks at $31.1^{\circ}$ (as the full-scale gypsum) and $29.1^{\circ}$, but no change in the filtration rate was obtained. It has not been possible in the pilot plant to form flat gypsum flakes with poor dewatering properties similar to those observed in full-scale plants.
\end{abstract}

\section{INTRODUCTION}

The combustion of fossil fuels, such as coal, oil, and natural gas, covers a substantial part of the global energy demand. Fuel resources can be efficiently utilized in combined heat and power plants with flue gas cleaning technologies, such as selective catalytic reduction (SCR), wet flue gas desulphurization (FGD), and electrostatic precipitation, installed to minimize emissions.

The wet flue gas desulphurisation process can remove acidic gases $\left(\mathrm{SO}_{2}, \mathrm{HCl}\right.$, and $\left.\mathrm{HF}\right)$ in an absorption step by bringing the flue gas into contact with an alkaline slurry, where the solids consist of finely ground limestone (with impurities such as silica, iron, and magnesium) and gypsum particles. ${ }^{1,2}$ The $\mathrm{HCl}$ and HF absorbed remain in solution, and the concentration of $\mathrm{Cl}^{-}$and other impurities are controlled by a purge stream. The $\mathrm{SO}_{2}$ dissociates to hydrogensulfite ions $\left(\mathrm{HSO}_{3}^{-}\right)$, which are again oxidized to sulfate ions $\left(\mathrm{SO}_{4}{ }^{2-}\right)$ by oxygen from air injection. Finally, $\mathrm{SO}_{4}{ }^{2-}$ ions combine with $\mathrm{Ca}^{2+}$ ions and crystallize as gypsum $\left(\mathrm{CaSO}_{4} \cdot 2 \mathrm{H}_{2} \mathrm{O}\right)$ according to the following equation

$$
\begin{aligned}
& \mathrm{CaCO}_{3}(\mathrm{~s})+\mathrm{SO}_{2}(\mathrm{~g})+2 \mathrm{H}_{2} \mathrm{O}(\mathrm{l})+1 / 2 \mathrm{O}_{2}(\mathrm{~g}) \\
& \rightarrow \mathrm{CaSO}_{4} \cdot 2 \mathrm{H}_{2} \mathrm{O}(\mathrm{s})+\mathrm{CO}_{2}(\mathrm{~g})
\end{aligned}
$$

In 1999 the gypsum producing wet scrubber constituted the majority $(>60 \%)$ of FGD capacity installed at power plants worldwide $^{1}$ and is still the dominant FGD technology today producing a significant part of the world's gypsum. The crystallization process includes the formation (nucleation) and growth of solid crystals from a supersaturated solution (SS). Super saturation is expressed mathematically by

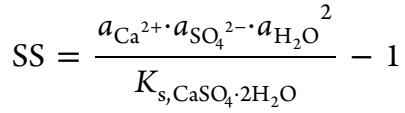

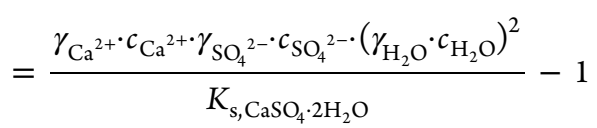

For growth to take place, SS must be positive. The particle size distribution (PSD) and morphology obtained depend on the growth rate (supersaturation-dependent) as well as the potential adsorption of foreign species onto specific crystal surfaces. ${ }^{3}$ The gypsum produced is withdrawn, washed, and dewatered using hydrocyclones, centrifuges, or vacuum belt filters until a commercial product is obtained. Commercial applications include wallboard and cement production and soil conditioning, for which different specifications apply, with respect to purity, moisture content (size and morphology dependent), and the content of different impurities (residual limestone and calcium sulphite, $\mathrm{CaSO}_{3} \cdot 2 \mathrm{H}_{2} \mathrm{O}$ ). Wet FGD gypsum crystals are usually 5-50 $\mu \mathrm{m}$, rhomboidal in shape, and of a high purity (>98\%), ${ }^{4}$ but quality issues, such as a decreased dewatering rate, can occur resulting in expenses for additional

Received: February 29, 2012

Revised: June 21, 2012

Accepted: July 5, 2012

Published: July 6, 2012 


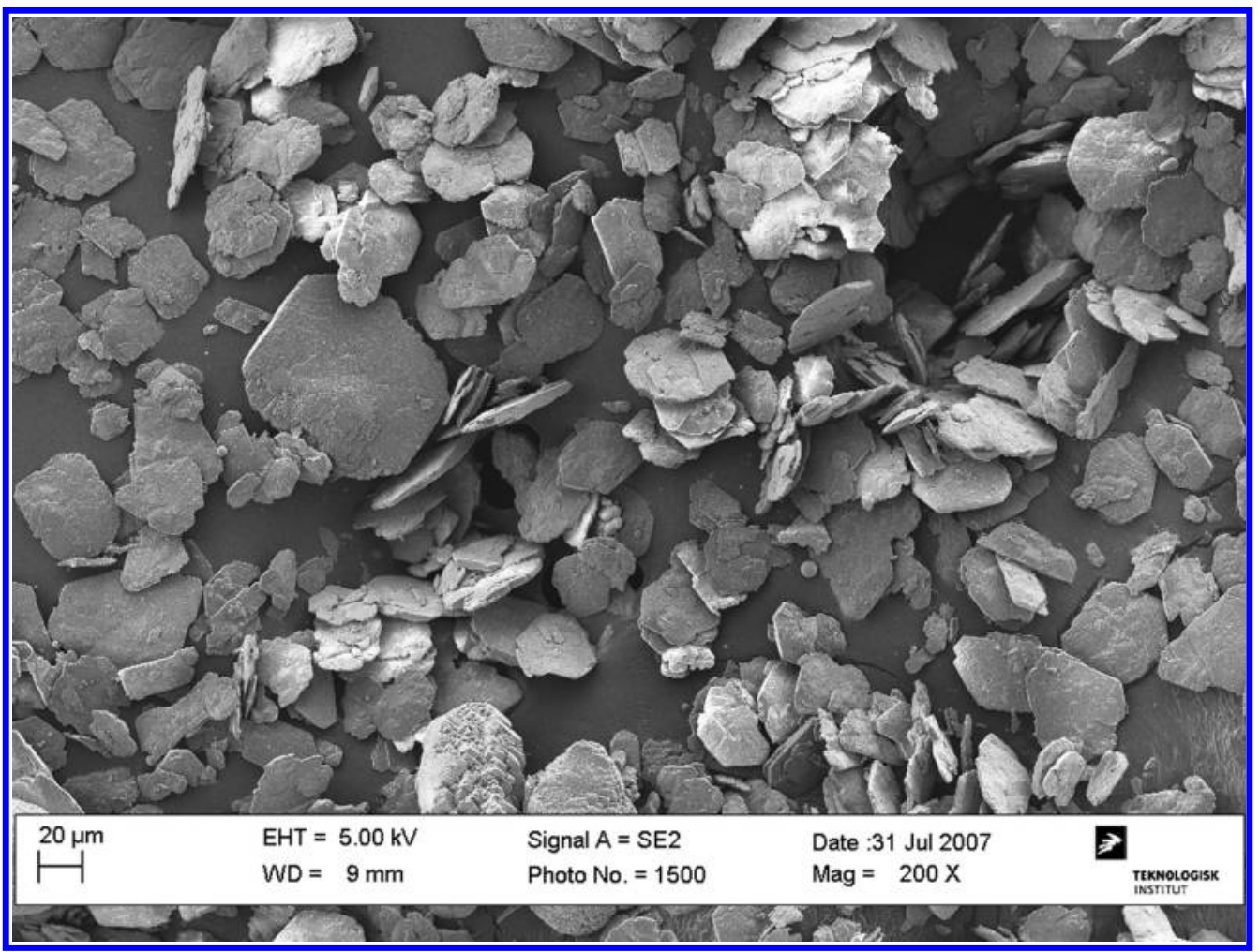

Figure 1. Scanning electron microscopy picture of flat gypsum crystals with poor dewatering properties. Reprinted with permission from the work of Hansen et al. ${ }^{5}$ Copyright 2011 Elsevier.

processing or disposal. Decreased dewatering rates may be caused by both increased levels of small particles and by morphology changes, which favor a closer packing of the gypsum crystals (Figure 1). Short residence times, excessive nucleation (high supersaturation) or breakage may decrease the particle size, while the crystal morphology can be affected by temperature, growth rate (supersaturation), and impurities as discussed in further details below

Commercial gypsum may also be obtained from other sources, for instance mining of deposits from brine evaporation or industrial processes such as phosphoric acid and hydrogen fluoride production. Differences in gypsum properties may result from different growth conditions such as temperature, concentration of salts, and humic compounds (organic constituents of soil). ${ }^{6}$ An increasing concentration of deprotonated humic compounds has been reported to favor gypsum twin/rosette aggregate morphologies, while high temperature and salinity $\left(60{ }^{\circ} \mathrm{C}\right.$ and $30 \% \mathrm{NaCl}$, respectively) yield blocky aggregates of bassanite $\left(2 \mathrm{CaSO}_{4} \cdot \mathrm{H}_{2} \mathrm{O}\right) .{ }^{6,7}$ Industrial gypsum may also exhibit different morphologies, probably due to the presence of specific impurities which occupy the most favorable binding sites, thereby affecting the rate of ion incorporation (crystal growth) and the resulting crystal morphology. ${ }^{3}$ Differences in the supersaturation of the liquid phase may also affect morphology, with higher degrees of supersaturation favoring longer and thinner needle-like crystals. ${ }^{8,9}$ Hemihydrate and gypsum formed during phosphoric acid production has in the presence of $0.100 \mathrm{~mol} / \mathrm{kg}$ aluminum fluoride complexes $\left(\mathrm{AlF}^{2+}\right.$ to $\left.\mathrm{AlF}_{6}{ }^{3-}\right)$ and elements from the lanthanides series (at a concentration of $0.0003 \mathrm{M}$ ) shown inhibited growth of specific crystal faces, changes in crystal morphology (toward flat shaped crystals), filterability, and washability of the filter cake, but it should be remembered that this process takes place at a lower supersaturation and higher temperatures (up to $90{ }^{\circ} \mathrm{C}$ ) than wet FGD. ${ }^{10-12}$ Iron, manganese, and magnesium have also been reported to negatively affect the dewatering performance of wet FGD gypsum. A contamination with $0.02 \mathrm{M} \mathrm{Mg}^{2+}$ or $\mathrm{Fe}^{3+}$ was enough to reduce the growth rate and change the crystal morphology toward needle-shaped crystals. ${ }^{2,10,13}$ In addition, breakage along characteristic mineral planes may also change the crystal morphology obtained-gypsum can exhibit perfect cleavage in one direction because of the water layers separating calcium-sulfate layers in the crystal lattice. ${ }^{14}$ Several studies on the theoretical predictions of gypsum equilibrium morphology (prismatic/rhombic) and growth morphology (flat/plate-like, due to water absorption) have furthermore been published. $^{15-17}$

In this work the dewatering properties of gypsum produced in a wet FGD pilot plant have been investigated and compared to wet FGD gypsum from a full-scale plant (Asnæs Power Plant Unit 2, DK) experiencing dewatering problems. The full-scale wet FGD plant in question is a CT-121 jet bubbling reactor and a dewatering system consisting of hydrocyclone batteries followed by a vacuum belt filter.

\section{STRATEGY OF INVESTIGATION}

This investigation of wet FGD gypsum dewatering properties is based on a series of pilot-scale experiments with different slurry compositions and residence times. The pilot plant enables a high degree of control of the experimental conditions such as gas phase composition, slurry $\mathrm{pH}$, and residence time. The conditions of the experiments performed have been chosen to investigate the effect of slurry composition (impurities, content of fines and flat crystals), solid concentration, and slurry residence time on gypsum PSD, morphology, and filtration rate. 


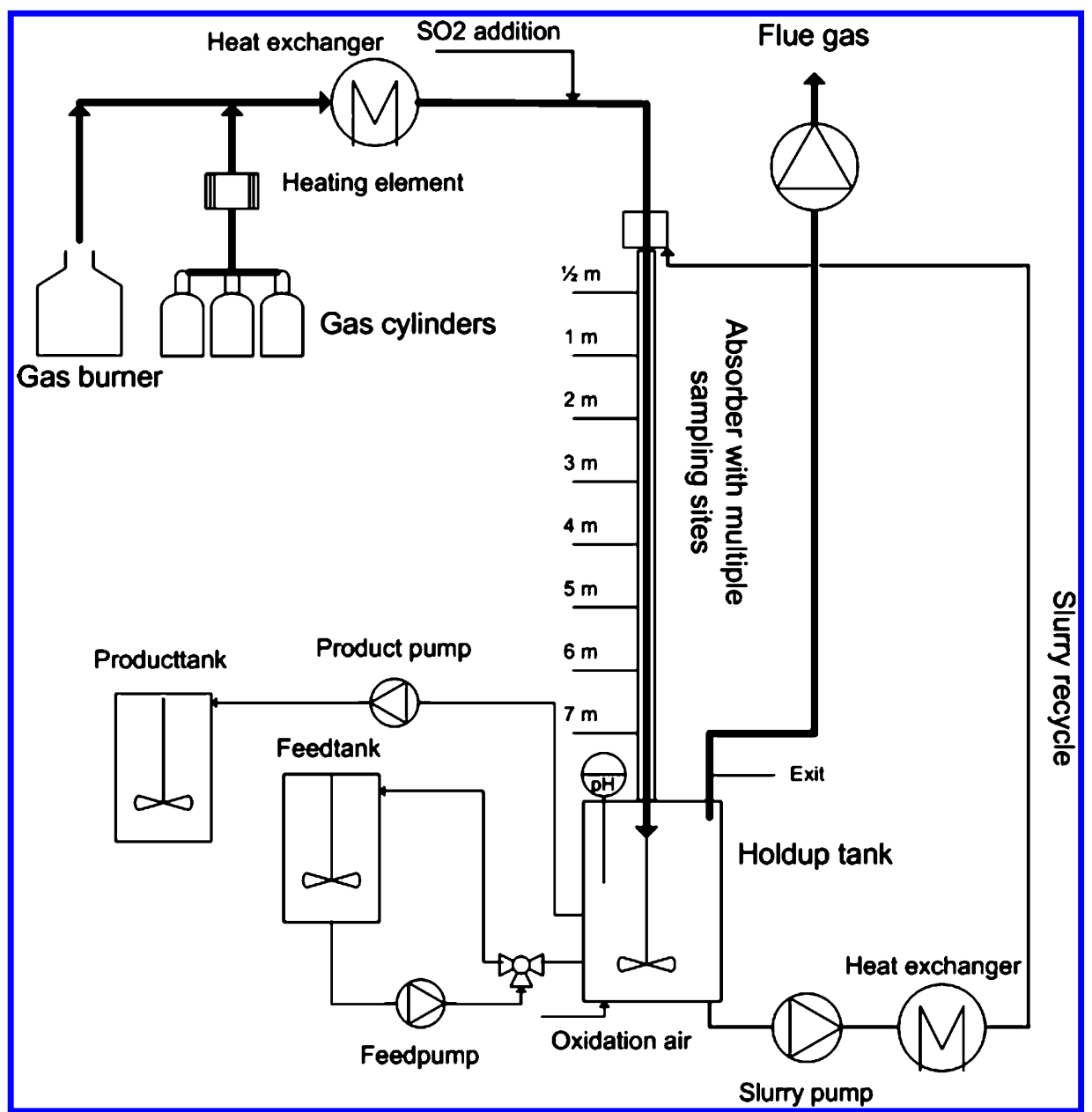

Figure 2. Outline of wet FGD pilot plant used in the experiments. The absorber is based on the falling film principle, and the gas and liquid phases flow cocurrently. Reprinted with permission from the work of Hansen et al. ${ }^{19}$ Copyright 2011 American Chemical Society.

Table 1. Overview of Experiments Performed and Operating Conditions ${ }^{a}$

\begin{tabular}{|c|c|c|c|c|c|c|}
\hline experiment & addition feed tank & addition holding tank & slurry $\tau(\mathrm{h})$ & flue gas $\left(\mathrm{N} \mathrm{m}^{3} / \mathrm{h}\right)$ & $\mathrm{SO}_{2} \operatorname{ppm}(\mathrm{v})$ & duration \\
\hline 1a: ASV2 slurry & ASV liquid phase ${ }^{b}$ & ASV slurry & 30 & 18 & 990 & $\sim 1 \tau$ \\
\hline 1b: base case & & & 30 & 17 & 950 & $\sim 21 /{ }_{2} \tau$ \\
\hline 2: seed crystals & ASV process water & AVV gypsum ${ }^{d}$ & 28 & 17 & 1030 & $\sim 2 \tau$ \\
\hline 3: $\mathrm{Al}_{2} \mathrm{~F}_{6}$ & $0.002 \mathrm{M} \mathrm{Al}_{2} \mathrm{~F}_{6}$ & $0.002 \mathrm{M} \mathrm{Al}_{2} \mathrm{~F}_{6}$ & 25 & 17 & 1000 & $\sim 2 \tau$ \\
\hline 4: quartz ${ }^{c}$ & $50 \mathrm{~g}$ quartz/1 & $50 \mathrm{~g}$ quartz/1 & 30 & 17 & 1030 & $\sim 5 \tau$ \\
\hline 5a. $\mathrm{Mg}^{2+}$ & $0.04 \mathrm{M} \mathrm{Mg}$ & $0.04 \mathrm{M} \mathrm{Mg}$ & 35 & 17 & 1010 & $\sim 3 \tau$ \\
\hline 5b: $\mathrm{Al}^{3+}$ & $0.02 \mathrm{M} \mathrm{Al}$ & $0.02 \mathrm{M} \mathrm{Al}$ & 27 & 17 & 1010 & $\sim 2 \tau$ \\
\hline 5c: base case & & & 30 & 17 & 980 & $\sim 1^{1} /{ }_{2} \tau$ \\
\hline $6: \tau=10 \mathrm{~h}$ & & & 10 & 18 & 980 & $\sim 5 \tau$ \\
\hline $7: \tau=80 \mathrm{~h}$ & & & 83 & 16 & 270 & $\sim 21 /{ }_{2} \tau$ \\
\hline 8a: $\tau=120 \mathrm{~h}$ high density & & & 122 & 17 & 510 & $\sim 1^{1} /{ }_{2} \tau$ \\
\hline $8 \mathrm{~b}:$ Breakage & & & & & & $408 \mathrm{~h}$ \\
\hline
\end{tabular}

${ }^{a} \tau=$ residence time. ${ }^{b}$ Coarse gypsum particles separated by sedimentation and liquid phase including fines used for limestone feed slurry. ${ }^{c} \mathrm{Quartz}$ $\operatorname{PSD}(20 \%<5 \mu \mathrm{m}) .{ }^{d}$ Gypsum from Avedøre Power Station (high filtration rate).

Aluminum fluoride complexes, $\mathrm{Mg}^{2+}, \mathrm{Al}^{3+}$, and full-scale slurry with high concentrations of fines ${ }^{18}$ have all been linked to morphology changes (inhibited growth of specific crystal faces) and poor dewatering properties. Long residence times and high solid concentrations can occur at full-scale wet FGD plants during low sulfur coal/biomass combustion at partial power plant load and these conditions create a potential for changes in PSD and morphology through breakage/attrition. Slurry samples were withdrawn and analyzed in terms of filtration time, PSD, morphology, and elemental composition (selected elements only).

\section{EXPERIMENTAL SETUP AND PROCEDURE}

Description of Setup. The wet FGD pilot plant, outlined in Figure 2, simulates a single vertical channel in a full-scale cocurrent flow wet FGD grid absorber. A $110 \mathrm{~kW}$ natural gas burner generates the flue gas and $\mathrm{SO}_{2}$ (AGA Gas $\mathrm{AB}$ ) is subsequently added before it is brought into contact with a 
slurry based on Faxe Bryozo limestone, with a purity above 97 wt \%, in the $7 \mathrm{~m}$ absorber. Multiple sampling sites along the absorber enable measurements of gas phase composition profiles and slurry $\mathrm{pH}$. The slurry is collected in a $110 \mathrm{~L}$ holding tank, where air injection, reactant addition (for maintaining a constant holding tank $\mathrm{pH}$ ), and slurry removal (for maintaining a constant slurry level) take place. From the holding tank, the slurry is recycled to the absorber, ensuring a liquid/gas ratio of $16-18 \mathrm{~L}$ slurry $/ \mathrm{m}^{3}$ flue gas (STP). Additional details concerning the pilot plant can be found in previous publications. ${ }^{20,21}$

Experimental Procedure. The experimental series were initiated by at least 2 days of desulphurisation of a $1000 \mathrm{ppm}(\mathrm{v})$ $\mathrm{SO}_{2}$ (g) flue gas stream using a feed stream containing $7.1 \mathrm{wt} \%$ Faxe Bryozo limestone. This allowed the system to approach steady state operation in terms of gypsum content, residual limestone content, and desulphurisation degree. The different operating conditions in Table 1 were then introduced one at a time and operation continued for at least one residence time (usually more). If an experiment is performed with the slurry from the preceding experiment, this is indicated by the use of the same "exp number" but with a letter (e.g., "a", "b") to distinguish experiments. Quartz was added in exp 4 to investigate the influence of fines, which has been linked to changes in morphology. ${ }^{18}$ A diluted feed stream was used to generate a short residence time in $\exp 6$, and a concentrated feed stream was used to the increase the slurry density (higher gypsum concentration) in exp 8a. Experiment $8 \mathrm{~b}$ investigates the influence of long-term breakage/attrition on crystal size and morphology while no crystal growth takes place, simulating wet FGD operation during low sulfur coal/biomass combustion at partial power plant load. Chemicals used include: $\mathrm{MgSO}_{4} \cdot 7 \mathrm{H}_{2} \mathrm{O}$ (Fluka 99\%), $\mathrm{AlCl}_{3} \cdot 6 \mathrm{H}_{2} \mathrm{O}$ (Sigma Aldrich 99\%), NaF (Sigma Aldrcih 99\%), and quartz powder (Ormslev kvartsværk "Kvartsmel" $\left.d_{20 \%}<5 \mu \mathrm{m}\right)$.

The limestone consumption (change in weight of feed tank), the flue gas flow rate (Flemco flowmeter), the holding tank $\mathrm{pH}$ (Yokogawa FU20), and the $\mathrm{SO}_{2}$ concentration (Rosemount NGA 2000) were monitored throughout the experiments. Each experiment was concluded by withdrawing two slurry samples from the holding tank for analysis of particle size distribution, crystal morphology, and filtration rate. The slurry samples for PSD analysis were stored for up to a few days at room temperature before analysis. The limited solubility of gypsum (about $2 \mathrm{~g} / \mathrm{L})$, compared to the slurry concentration $(>100 \mathrm{~g} /$ $\mathrm{L})$, and its invariability with temperature ${ }^{22}$ ensured that no major changes in PSD took place during storage, as has been previously verified. ${ }^{23}$ Two individual PSD analyses were performed by laser diffraction (Malvern Mastersizer S longbed) on an ethanol/slurry dispersion of each sample, all analyses representing the average of 5 measurements. The filtration rate was obtained by measuring the time it took the $80 \mathrm{~mL}$ slurry sample to pass through a $0.45 \mu \mathrm{m}$ filter in a Büchner funnel. The collected crystals were subsequently dried at $40{ }^{\circ} \mathrm{C}$ and used to study the morphology and crystallographic structure by scanning electron microscopy (FEI Inspect $S$ ) and X-ray powder diffraction (PANalytical X'pert PRO Diffractimeter). Information on the crystallographic structure/crystal lattice planar distance $(\mathrm{d})$ is obtained by applying Bragg's law $(n \lambda=2 d$ $\sin \Theta$ ) for a range of incident angles $(\Theta)$. A few samples were furthermore screened in terms of the elemental composition of the liquid and solid phase, and the concentration of selected elements ( $\mathrm{Al}, \mathrm{Na}, \mathrm{Cl}, \mathrm{F}$ ) was determined. The samples for analysis of the ionic liquid composition were passed through a $0.45 \mu \mathrm{m}$ filter and diluted 1:2 with laboratory grade pure water to prevent further precipitation. The solid crystals (collected from the filter) were either dissolved in a warm mixture of acids ( $\mathrm{HF}$ and $\mathrm{HNO}_{3}$ ), neutralized by $\mathrm{H}_{3} \mathrm{BO}_{3}$, and analyzed by inductively coupled plasma optical emission spectrometry (Perkin-Elmer Optima 3000 ICP-OES) for cation detection or dissolved in excess laboratory grade pure water and analyzed by ICP-OES (Spectro Ciros-CCD) for anion detection.

\section{RESULTS AND DISCUSSION}

The experimental work includes 12 wet FGD experiments using different slurry compositions $(1 \mathrm{a}-5 \mathrm{c})$, solids content (7$8 b)$, and residence times $(5 c-8 b)$ to investigate their impact on gypsum particle size distribution, morphology, and filtration rate. Details of the experiments are given in Table 1.

Effect of Experimental Conditions on Filtration Rate. The filtration times and slurry solids concentrations of the experiments performed are shown in Table 2. The diluted

Table 2. Filtration Time, Mass Collected, and Slurry Solid Concentration $^{a}$

$\begin{array}{lccc}\quad \text { experiment } & \begin{array}{c}\text { filtration time } \\ ( \pm 10 \mathrm{~s})\end{array} & \begin{array}{c}\text { mass } \\ \text { collected }(\mathrm{g})\end{array} & \begin{array}{c}\text { concentration } \\ (\mathrm{g} / \mathrm{L})\end{array} \\ \begin{array}{l}\text { 1a: ASV2 slurry } \\ \text { (before) }\end{array} & 1200 & 5.6 & 84 \\ \begin{array}{l}\text { 1a: ASV2 slurry } \\ \text { (after) }\end{array} & 180 & 8.0 & 116 \\ \text { 1b: base case } & & & \\ \text { 2: seed crystals } & 60 & 6.8 & 125 \\ \text { 3: } \mathrm{Al}_{2} \mathrm{~F}_{6} & 50 & 7.8 & 105 \\ \text { 4: quartz } & 45 & 10.0 & 129 \\ \text { 5a. } \mathrm{Mg}^{2+} & 75 & 11.6 & 132 \\ \text { 5b: } \mathrm{Al}^{3+} & 55 & 6.5 & 80 \\ \text { 5c: base case } & 65 & 6.5 & 77 \\ \text { 6: } \tau=10 \mathrm{~h} & 140 & 8.0 & 27 \\ \text { 7: } \tau=80 \mathrm{~h} & 65 & 8.0 & 99 \\ \text { 8a } \tau=120 \mathrm{~h} \text { high } & 55 & 13.9 & 169 \\ \text { density } & & & \\ \text { 8b: breakage } & 170 & 18.1 & 280 \\ { }^{\tau} \tau=\text { residence time. } & & & \\ \end{array}$

limestone feed stream used in the experiment with a short residence time $(\tau=10 \mathrm{~h})$ also causes a lower solids concentration. The solids concentrations in the base case and the $\mathrm{Al}^{3+}$ experiments are also below the average, due to a minor water leak from an external water tank entering the system through the air injection line. Experiments $5 \mathrm{a}\left(\mathrm{Mg}^{2+}\right), 5 \mathrm{~b}$ $\left(\mathrm{Al}^{3+}\right)$, and 5c (base case), with very similar particle size distributions and morphologies (will be illustrated in the next sections) yield reasonably consistent filtration times (75, 55, and $65 \mathrm{~s}$, respectively)

The filtration time of the full-scale slurry (exp 1a, $1200 \mathrm{~s}$ ) differs significantly from the other experiments (generally about $60 \mathrm{~s}$ ), including an experiment with seed crystals from Avedøre power plant $(\exp 2)$. However, gypsum crystals formed in the pilot plant in the presence of ASV2 liquid phase show a highly reduced filtration time (about $180 \mathrm{~s}$ ). The gypsum produced at short residence times and after $408 \mathrm{~h}$ attrition/breakage both showed slightly increased filtration times (140-170 s). The filtration rate may be affected by mechanisms changing the morphology or the PSD, this will be discussed in further detail in the following sections. 
Effect of Process Parameters on Gypsum Particle Size Distribution. Figures 3 and 4 and Table 3 show the particle

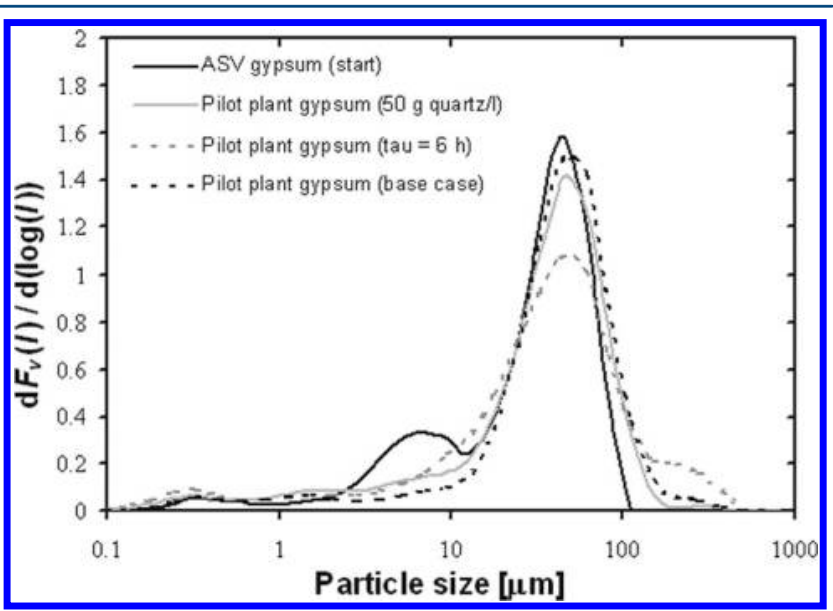

Figure 3. Particle size distribution (frequency curves) of selected experiments.

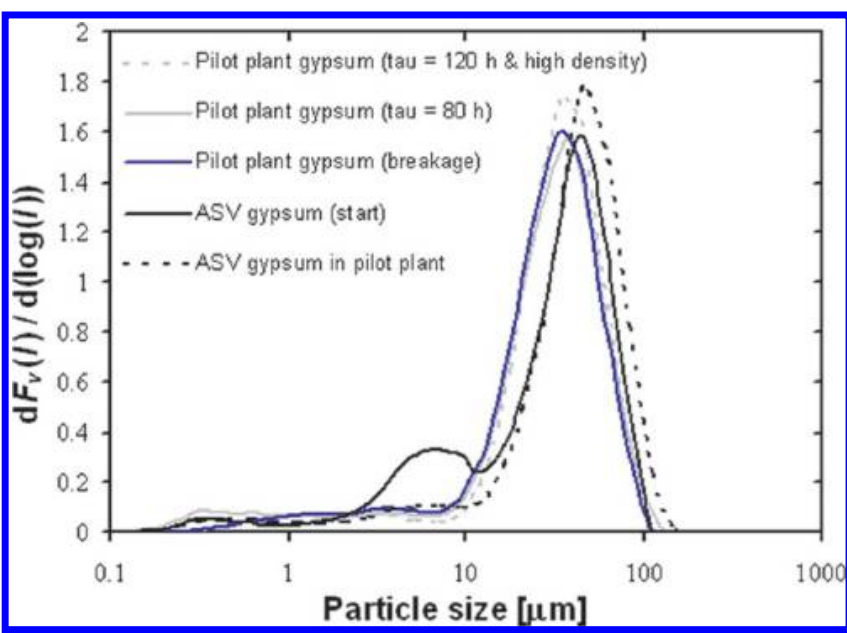

Figure 4. Particle size distribution (frequency curves) of selected experiments.

Table 3. Volumetric Mean Particle Size $\left(D_{50 \%}\right)^{a}$

$\begin{array}{ll}\quad \quad \quad \text { experiment } & D_{50 \%}(\mu \mathrm{m}) \\ \text { 1a: ASV2 slurry (before) } & 34.5 \pm 0.1 \\ \text { 1a: ASV2 slurry (after) } & 42.5 \pm 0.1 \\ \text { 1b: base case } & \\ \text { 2: seed crystals } & \\ \text { 3: } \mathrm{Al}_{2} \mathrm{~F}_{6} & \\ \text { 4: quartz } & 39.4 \pm 0.3 \\ \text { 5a. } \mathrm{Mg}^{2+} & 46.0 \pm 1.0 \\ \text { 5b: } \mathrm{Al}^{3+} & 45.1 \pm 0.1 \\ \text { 5c: base case } & 44.1 \pm 0.1 \\ \text { 6: } \tau=10 \mathrm{~h} & 38.6 \pm 0.2 \\ \text { 7: } \tau=80 \mathrm{~h} & 31.3 \pm 0.2 \\ \text { 8a } \tau=120 \mathrm{~h} \text { high density } & 33.9 \pm 0.1 \\ \text { 8b: breakage } & 31.1 \pm 0.1\end{array}$

${ }^{a_{\tau}}=$ residence time.

size distribution and the volumetric mean particle diameter, respectively. The base case particle size distribution and mean particle size corresponds well with previously published data from the pilot plant $\left(d_{50}=42.8 \mu \mathrm{m}\right)^{5}$ while it was slightly lower in fines than previously investigated gypsum from full-scale plants $\left(d_{50}=34.9-41.3 \mu \mathrm{m}\right) .^{5} \mathrm{~A}$ high mean particle size and good filtration properties were obtained for the base case experiment as well as experiments with $\mathrm{Al}^{3+}$ and $\mathrm{Mg}^{2+}$ addition. A lower mean particle size is obtained in the experiments with quartz addition and long residence times, but short filtration times are still obtained. The particle size distributions in these experiments are shifted toward smaller particles, but without any significant changes in the level of particles smaller than 10 $\mu \mathrm{m}$. The experiments with full-scale slurry, short residence times, and $408 \mathrm{~h}$ breakage (1a, 1b, 6, and $8 \mathrm{~b}$ ) yield a lower mean particle size, higher levels of particles below $10 \mu \mathrm{m}$ (least pronounced in exp $8 \mathrm{~b}$ ), and longer filtration times (especially for the full-scale slurry). A short residence time means less growth time for the crystals, thereby yielding smaller crystals, while the experiments with longer residence times $(7,8 a$, and $8 \mathrm{~b})$ may facilitate breakage/attrition and a slower crystal growth rate (a lower $\mathrm{SO}_{2}$ concentration was used yielding a lower supersaturation). Fine particles may furthermore be introduced into a full-scale plant via dust in the flue gas, impurities in the process water and excessive nucleation

Effect of Experimental Conditions on Crystal Morphology. The crystals formed during the base case experiment were columnar shaped (Figure 5), corresponding well with the

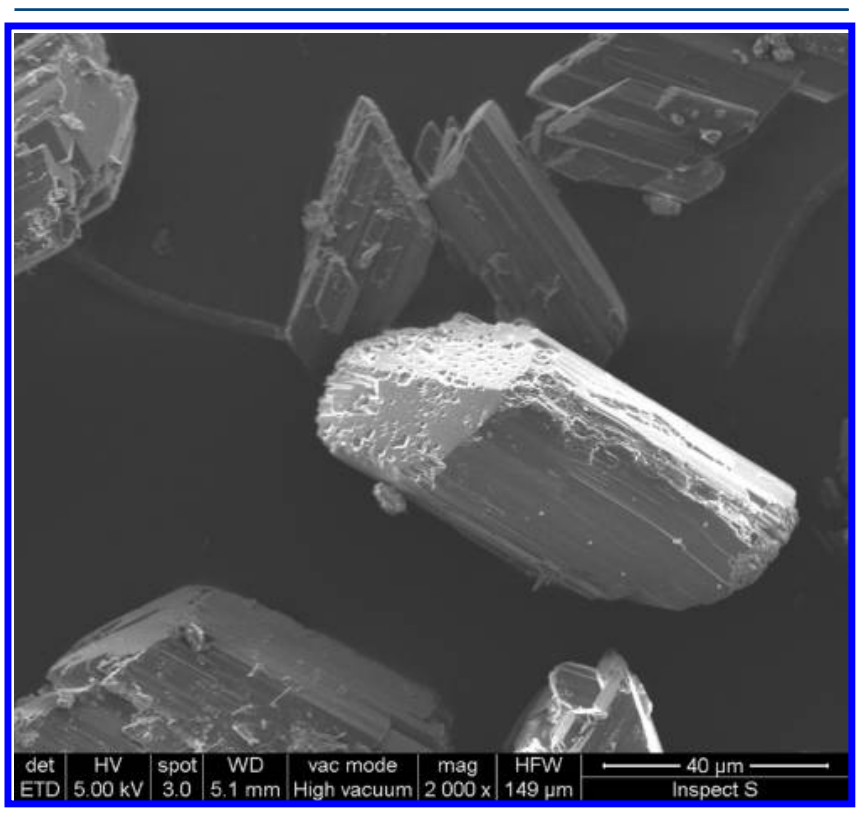

Figure 5. Scanning electron microscopy picture of gypsum crystals from the base case experiment (exp 5c). Experimental conditions can be found in Table 1 .

morphologies reported in literature at lower degrees of saturation $(S \leq 1.2))^{7,8}$ A similar morphology was obtained in experiments with $\mathrm{Al}_{2} \mathrm{~F}_{6}(\exp 3)$, quartz $(\exp 4), \mathrm{Mg}^{2+}(\exp 5 \mathrm{a})$, $\mathrm{Al}^{3+}(\exp 5 \mathrm{~b})$, and a prolonged residence time (exp 7), the crystals in the latter experiment were, however, a bit more compact. The strongest X-ray diffraction peak of these gypsum samples (Figure 6) was at $11.6^{\circ}$ (020 face), with strong and moderate peaks at $20.7^{\circ}$ (-1-21 face), $23.4^{\circ}$ (040 face), $29.1^{\circ}$ (-1-41 face), and an additional moderate peak at $31.1^{\circ}(121$ face) for the gypsum with quartz addition and the gypsum formed at a prolonged residence time. The peaks at $20.7^{\circ}$ and $29.1^{\circ}$ were more distinct in the base case gypsum than in the other samples. The shorter residence time, lower gypsum 


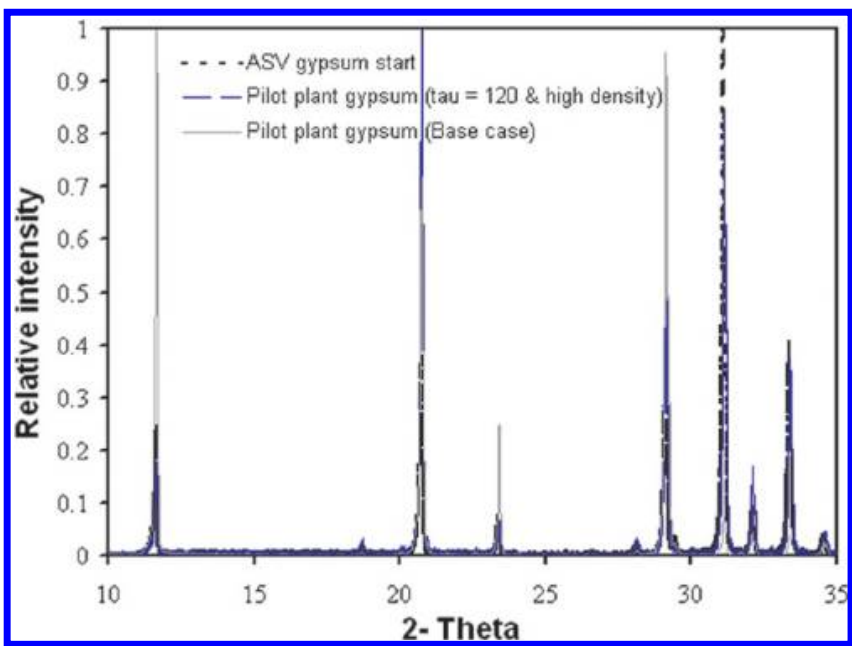

Figure 6. XRD patterns for selected samples $(\mathrm{Cu} \mathrm{K} \alpha 1)$.

concentration, and, thereby, potentially higher supersaturation (not measured) in experiment 6 formed more elongated crystals (Figure 7) compared to the other experiments, also in

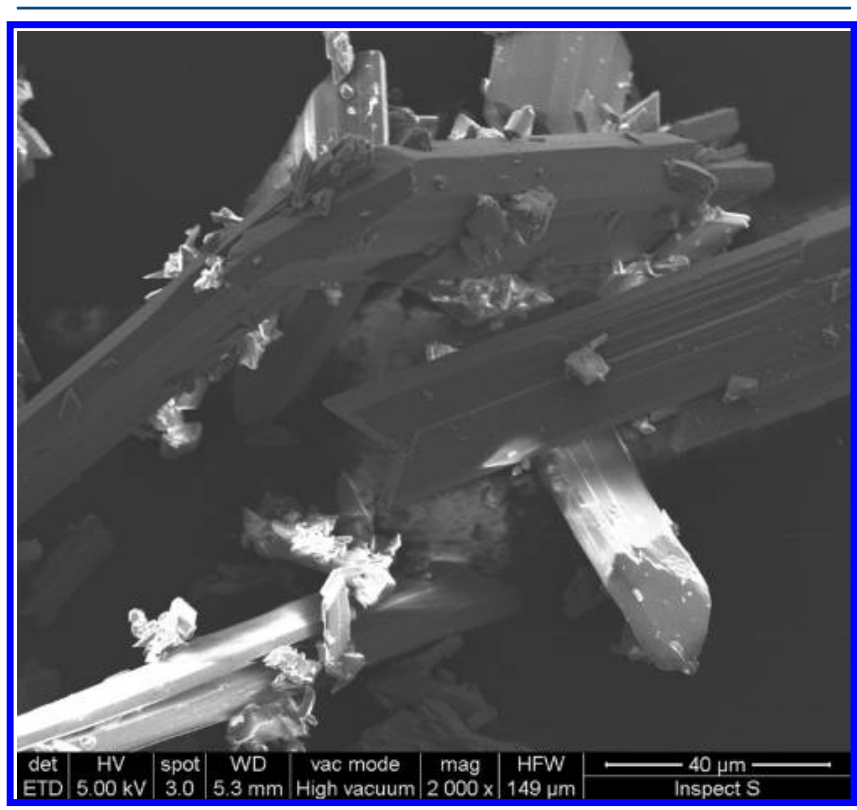

Figure 7. Scanning electron microscopy picture of gypsum crystals formed at a short solids residence time (exp $6 \tau=10 \mathrm{~h})$. Experimental conditions can be found in Table 1 .

agreement with other investigations. ${ }^{8,9}$ The strongest X-ray diffraction peak was still at $11.6^{\circ}$ (020 face), with moderate peaks at $20.7^{\circ}, 23.4^{\circ}$, and $29.1^{\circ}$. The thin gypsum flakes from the full-scale wet FGD plant differed significantly from the crystals from all other experiments. The crystal aspect ratio did, however, decrease, and the filtration rate increase, in the pilot plant during growth in the presence of ASV liquid phase (experiment 1a, see Figure 8 ). The strongest X-ray diffraction peak was at $31.1^{\circ}$ with moderate peaks at $11.6,20.7^{\circ}, 29.1^{\circ}$, $33.3^{\circ}$ (051 face), and $35.9^{\circ}$ (200 face). The intensity of the $20.7^{\circ}$ and $29.1^{\circ}$ peaks increased significantly during experiment 1a. Crystals formed at higher solids concentrations, and longer residence times $(\exp 8 \mathrm{a})$ showed a higher proportion of flat crystals (as in Figure 8) and strong XRD peaks at $20.7^{\circ}$ (strongest), $29.1^{\circ}$, and $31.1^{\circ}$, while crystals exposed to long-

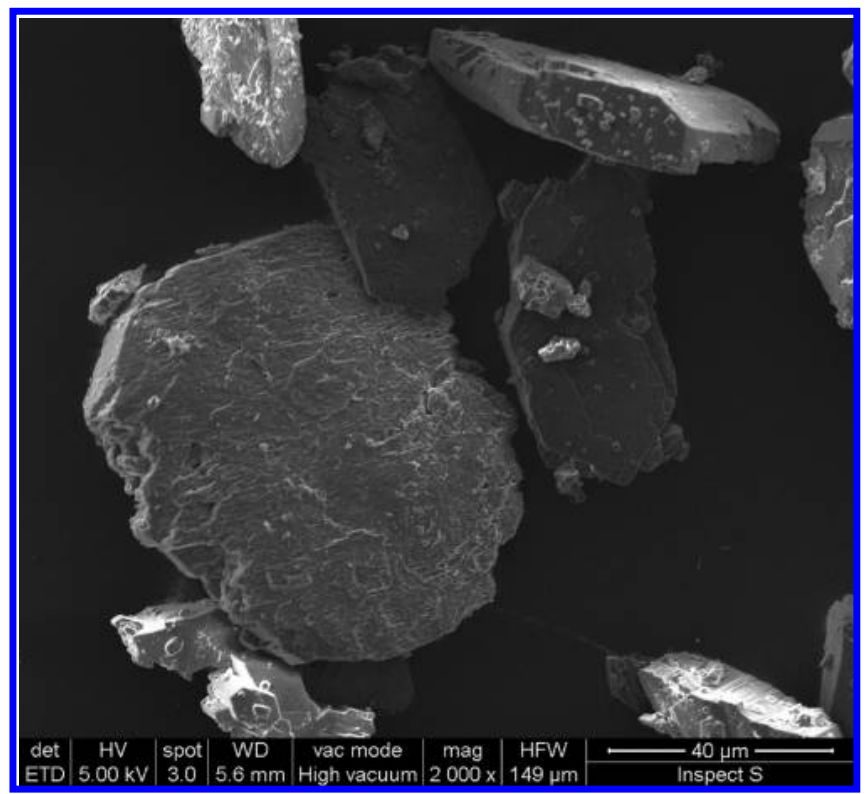

Figure 8. Scanning electron microscopy picture of gypsum crystals formed in the pilot plant with slurry from full-scale plant (exp 1a). Experimental conditions can be found in Table 1 .

term attrition (exp $8 \mathrm{~b})$ showed similar XRD peaks $\left(29.1^{\circ}\right.$ and $31.1^{\circ}$ were slightly more powerful) and more rounded shapes (Figure 9), similar to gypsum from full-scale wet FGD plants. ${ }^{5}$

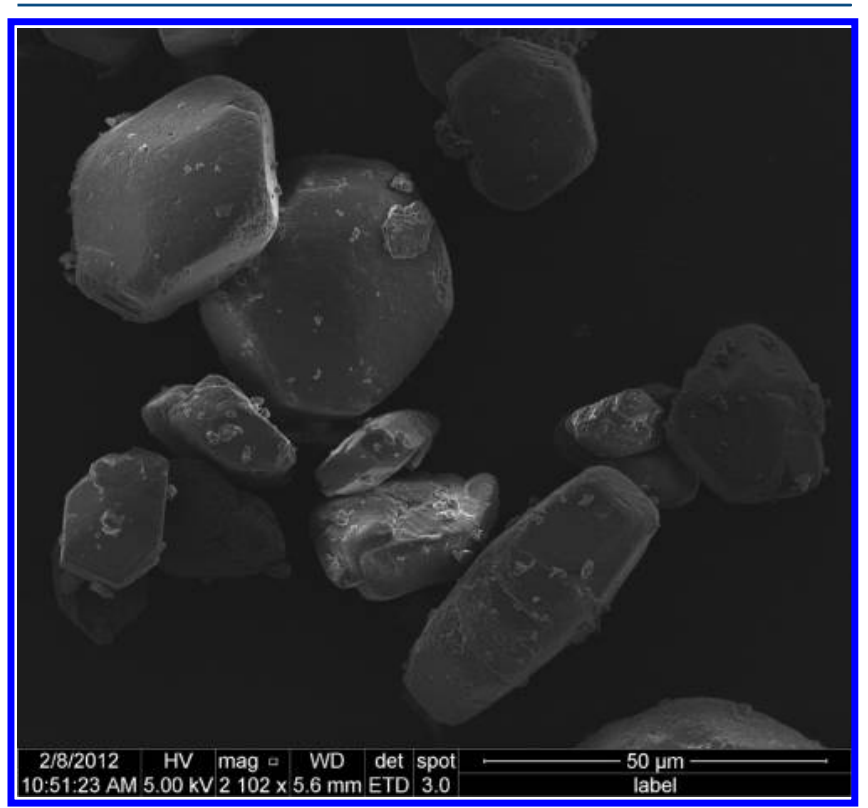

Figure 9. Scanning electron microscopy picture of gypsum crystals formed at high solids concentration and long residence time (exp 8a $\tau$ $=120 \mathrm{~h}$ ). Experimental conditions can be found in Table 1 .

The flatter crystals formed at higher solids concentrations and longer residence times (exp 8a) also possessed the strong XRD peak at $31.1^{\circ}$ seen for the ASV2 gypsum, but also a much stronger $29.1^{\circ}$ peak, and the morphology change did not affect the filtration rate. In summary, none of the pilot plant experiments performed could form the flat ASV2 gypsum crystals associated with low filtration rates.

Gypsum Slurry Impurities. The X-ray diffraction analysis identified gypsum as the major compound in all samples, but 
changes in crystals morphology are often associated with adsorption of small amounts impurities onto specific crystal faces, thereby affecting the rate of ion incorporation (crystal growth) and the resulting morphology. Table 4 shows the

Table 4. Content of Selected Elements in Gypsum and Liquid Phase

\begin{tabular}{|c|c|c|c|c|c|c|}
\hline sample & & $\mathrm{Al}$ & $\mathrm{Na}$ & $\mathrm{Cl}$ & $\mathrm{F}$ & $\mathrm{P}$ \\
\hline \multirow{2}{*}{$\begin{array}{l}\text { 1a: ASV2 } \\
\text { slurry } \\
\text { (before) }\end{array}$} & gypsum $^{a}$ & 0.13 & 0.069 & 0.15 & 0.35 & 0.021 \\
\hline & liquid $^{b}$ & $<2$ & 1200 & 3200 & 11.2 & $<2$ \\
\hline \multirow{2}{*}{$\begin{array}{c}\text { 1a: ASV2 } \\
\text { slurry } \\
\text { (after) }\end{array}$} & gypsum $^{a}$ & & & 0.12 & 0.089 & \\
\hline & liquid $^{b}$ & & & & & \\
\hline \multirow[t]{2}{*}{ 1b: base case } & gypsum $^{a}$ & 0.028 & 0.009 & 0.014 & $<0.040$ & 0.014 \\
\hline & liquid $^{b}$ & $<2$ & 300 & 900 & 8.2 & $<2$ \\
\hline
\end{tabular}

concentration of selected impurities $(\mathrm{Al}, \mathrm{Na}, \mathrm{Cl}, \mathrm{F}$, and $\mathrm{P})$ for six full-scale and pilot-scale samples (three with solid gypsum and three with liquid phase). The impurities initially present in the ASV2 gypsum gradually disappear in the pilot plant (exp 1a), and the crystal thickness and filtration rate increase, despite the use of the liquid phase from the full-scale slurry. Traces of iron, potassium, magnesium, silicon, and titanium were furthermore detected in addition to high levels of calcium (from gypsum). Pilot scale experiments with $\mathrm{Al}^{3+}, \mathrm{Mg}^{2+}$, and $\mathrm{F}^{-}$ added showed no effect of these species on gypsum morphology. The elements present in wet FGD systems depend on fly ash escaping the particulate filter, gaseous elements absorbed, and impurities from limestone and process water. The elements measured in this work correspond well with other investigations, but additional species such as zinc, copper, manganese, molybdenum, and vanadium may also be encountered. ${ }^{4}$

\section{CONCLUSION}

A systematic pilot-scale investigation of wet FGD gypsum dewatering properties has demonstrated that high quality gypsum with favorable dewatering properties can be produced in a pilot scale setup over a wide range of operating conditions. A decreased holding tank solids residence time (from 30 to 10 h) did, however, yield elongated crystals, an XRD pattern dominated by a strong peak at $11.6^{\circ}$ (peaks at $20.7^{\circ}$ and $29.1^{\circ}$ were less powerful than in the base case), a higher fraction of fines, and a slightly lower filtration rate, possibly due to higher degrees of supersaturation. Long-term attrition (408 h) also shifted the PSD toward smaller particles and decreased the filtration rate. Gypsum from a full-scale plant experiencing dewatering problems contained an increased fraction of fines and had a significantly different morphology (thin gypsum flakes) and XRD pattern (dominated by a strong peak at $31.1^{\circ}$ ). The properties of these crystals did, however, improve (and the impurity content decreased) during subsequent growth in the pilot plant both in the presence of liquid phase from the full-scale plant and demineralised water. A shift toward flatter crystals was obtained at higher solids concentrations and longer residence times (169 g/L and 120 $\mathrm{h}$ ), and the XRD pattern contained strong peaks at $31.1^{\circ}$ (as the full-scale gypsum) and $29.1^{\circ}$, but the morphology change did not affect the filtration rate.
An increased processing time may to some extent overcome poor dewatering properties, but efforts to change the PSD or morphology should also be considered. The presence of growth retarding species may significantly influence the gypsum PSD and morphology $-{ }^{3}$ but no specific compounds were identified to be of importance in the present study. This effect may be reduced by an increased wastewater withdrawal, optimization of the preceding particulate control device, a change in the limestone source, and process water pretreatment. High degrees of supersaturation may furthermore increase nucleation rate and favor needle-like crystals. The supersaturation in a wet FGD plant is influenced by the sulfur content of the fuel used, the desulphurisation degree as well as the total crystal area available for growth. Finally, an increased slurry volume or solids concentration can provide both potentially positive (longer residence time) and negative effects (increased exposure to breakage or attrition and an increased surface area due to lower growth rate).

\section{AUTHOR INFORMATION}

\section{Corresponding Author}

*Telephone: +45 45252829. Fax: +45 45882258. E-mail: bbh@ kt.dtu.dk.

\section{Notes}

The authors declare no competing financial interest.

\section{ACKNOWLEDGMENTS}

The authors wish to thank technician Anders Tiedje for technical assistance and engineers Dorthe Dixen (DONG Energy A/S), Folmer Fogh (DONG Energy A/S), Niels Ole Knudsen (formerly Vattenfall A/S), Maria Friberg Andersen (Burmeister \& Wain Energy A/S), and Nicholas Kristensen (Burmeister \& Wain Energy A/S) for helpful scientific discussions. The authors would furthermore like to acknowledge the Center for Electron Nanoscopy (DTU Cen) for assistance with SEM images and XRD analysis. Financial support by DONG Energy A/S and Vattenfall A/S (grant no. 1-00550 and V3-203) is gratefully acknowledged.

\section{NOMENCLATURE}

$a=$ activity $[\mathrm{M}]$

$c=$ concentration $[\mathrm{M}]$

$d=$ crystal lattice planar distance

$D_{20 \%}=$ particle size under which $20 \%$ of the total volume is located $[\mu \mathrm{m}]$

$D_{50 \%}=$ volumetric mean diameter $[\mu \mathrm{m}]$

$F_{v}=$ cumulative volumetric distribution $[-]$

$K_{\mathrm{s}}=$ solubility product $\left[\mathrm{M}^{2}\right]$

$l=$ particle size $[\mu \mathrm{m}]$

$n=$ order of reflection

$\mathrm{SS}=$ degree of super saturation $[-]$

$\gamma=$ activity coefficient $[-]$

$\Theta=$ incident $\mathrm{X}$-ray angle

$\lambda=\mathrm{X}$-ray wavelength

\section{REFERENCES}

(1) Soud, H. N. Developments in FGD; IEA Coal Research: London, 2000.

(2) Buecker, B. Qualities of Limestone That Influence Wet FGD Performance. Power Eng. 2011, 115 (6), 34-36.

(3) Davey, R. J.; Garside, J. From Molecules to Crystallizers; Oxford University Press: Oxford, 2000. 
(4) Koukouzas, N; Vasilatos, C. Mineralogical and chemical properties of FGD gypsum from Florina, Greece. J. Chem. Technol. Biotechnol. 2008, 83 (1), 20-26.

(5) Hansen, B. B.; Kiil, S.; Johnsson, J. E. Investigation of the gypsum quality at three full-scale wet flue gas desulphurisation plants. Fuel 2011, 90 (10), 2965-2973.

(6) Warren, J. K. Evaporites: Sediments, Resources and Hydrocarbons; Springer: Berlin, 2006.

(7) Cody, R. D.; Cody, A. M. Gypsum Nucleation and Crystal Morphology in Analog Saline Terrestrial Environments. J. Sedimen. Petrol. 1988, 58, 247-255.

(8) Abdel-Aal, E. A.; Rashed, M. M.; El-Shall, H. Crystallization of calcium dehydrate at different supersaturation ratios and different free sulphate concentrations. Cryst. Res. Technol. 2004, 39 (4), 313-321.

(9) Bunn, C. W. Chemical Crystallography-an introduction to optical and $x$-ray methods; Oxford University press: Oxford, 1961.

(10) Gao, X.; Huo, W.; Zhong, Y.; Luo, Z.-Y.; Cen, K.-F.; Ni, M.-J.; Chen, L.-M. Effects of Magnesium and Ferric Ions on Crystallization of Calcium Sulfate Dihydate Under the Simulated Conditions of Wet Flue-gas Desulfurisation. Chem. Res. Chin. Univ. 2008, 24 (6), 688693.

(11) Koopman, C.; Witkamp, G. J. Ion exchange extraction during continuous recrystallization of $\mathrm{CaSO}_{4}$ in the phosphoric acid production process: lanthanide extraction efficiency and $\mathrm{CaSO}_{4}$ particle shape. Hydrometallurgy 2002, 63 (2), 137-147.

(12) Martynowicz, E. T. M. J. Impurity uptake in calcium sulphate during phosphoric acid processing; Delft University of Technology: Delft, 1994.

(13) Blythe, G. M. Results of Full-Scale Utility FGD $\mathrm{SO}_{2}$ removal upgrade testing. Tenth Annual Coal Preparation, Utilization, and Environmental Control Contractors Conference, Pittsburgh, July 18-21, 1994.

(14) Roberts, W. L.; Rapp, G. R.; Weber, J. Encyclopedia of Minerals; Van Nostrand Reinhold: New York, NY, 1974.

(15) Rubbo, M.; Massaro, F. R.; Aquilano, D.; Vanzetti, W. Morphology of gypsum: a case study. Cryst. Res. Technol. 2011, 46 (8), 779-783.

(16) Massaro, F. R.; Rubbo, M.; Aquilalo, D. Theoretical Equilibrium Morphology of Gypsum $\left(\mathrm{CaSO}_{4} \cdot 2 \mathrm{H}_{2} \mathrm{O}\right)$. 1. A Syncretic Strategy to Calculate the Morphology of Crystals. Cryst. Growth Des. 2010, 10 (7), 2870-2878.

(17) Massaro, F. R.; Rubbo, M.; Aquilalo, D. Theoretical Equilibrium Morphology of Gypsum $\left(\mathrm{CaSO}_{4} \cdot 2 \mathrm{H}_{2} \mathrm{O}\right)$. 2. The Stepped Faces of the Main [001] Zone. Cryst. Growth Des. 2011, 11 (5), 1607-1614.

(18) Gebhard, G.; Uerpmann, E. P. Gypsum grain shape and gypsum grain size-effects of method of operation of flue gas desulphurization. VGB Kraftwerkstechnik 1988, 68 (8), 843-853.

(19) Hansen, B. B.; Fogh, F.; Knudsen, N. O.; Kiil, S. Performance of a Wet Flue Gas Desulfurization Pilot Plant under Oxy-Fuel Conditions. Ind. Eng. Chem. Res. 2011, 50 (8), 4238-4244.

(20) Kiil, S. Experiments and theoretical investigations of wet flue gas desulphurization. Ph.D. Thesis, Department of Chemical Engineering, Technical University of Denmark: Lyngby, Denmark, 1998.

(21) Kiil, S.; Michelsen, M. L.; Dam-Johansen, K. Experimental investigation and modelling of a wet flue gas desulphurisation pilot plant. Ind. Eng. Chem. Res. 1998, 37, 2792-2806.

(22) Lide, D. R., Ed. CRC handbook of chemistry and physics, 88th ed.; Taylor and Francis: Boca Raton, FL, 2007; internet version 2008, http://www.hbcpnetbase.com.

(23) Lyregaard, M.; Rabia, O. Vad røggasafsvovling. BEng Thesis, Technical University of Denmark: Kgs Lyngby; 2000 [in Danish]. 